\title{
Contrasts between estimates of baseflow help discern multiple sources of water contributing to rivers
}

\author{
I. Cartwright ${ }^{1,2}$, B. Gilfedder ${ }^{1,2, *}$, and H. Hofmann ${ }^{1,2}$ \\ ${ }^{1}$ School of Geosciences, Monash University, Clayton, Vic. 3800, Australia \\ ${ }^{2}$ National Centre for Groundwater Research and Training, G.P.O. Box 2100, Flinders University, \\ Adelaide, SA 5001, Australia \\ * now at: Limnologische Forschungsstation, Universität Bayreuth, Universitätsstr. 30, 95447 Bayreuth, Germany
}

Correspondence to: I. Cartwright (ian.cartwright@monash.edu)

Received: 6 May 2013 - Published in Hydrol. Earth Syst. Sci. Discuss.: 14 May 2013

Revised: 19 November 2013 - Accepted: 28 November 2013 - Published: 3 January 2014

\begin{abstract}
This study compares baseflow estimates using chemical mass balance, local minimum methods, and recursive digital filters in the upper reaches of the Barwon River, southeast Australia. During the early stages of highdischarge events, the chemical mass balance overestimates groundwater inflows, probably due to flushing of saline water from wetlands and marshes, soils, or the unsaturated zone. Overall, however, estimates of baseflow from the local minimum and recursive digital filters are higher than those based on chemical mass balance using $\mathrm{Cl}$ calculated from continuous electrical conductivity measurements. Between 2001 and 2011, the baseflow contribution to the upper Barwon River calculated using chemical mass balance is between 12 and $25 \%$ of the annual discharge with a net baseflow contribution of $16 \%$ of total discharge. Recursive digital filters predict higher baseflow contributions of 19 to $52 \%$ of discharge annually with a net baseflow contribution between 2001 and 2011 of $35 \%$ of total discharge. These estimates are similar to those from the local minimum method (16 to $45 \%$ of annual discharge and $26 \%$ of total discharge). These differences most probably reflect how the different techniques characterise baseflow. The local minimum and recursive digital filters probably aggregate much of the water from delayed sources as baseflow. However, as many delayed transient water stores (such as bank return flow, floodplain storage, or interflow) are likely to be geochemically similar to surface runoff, chemical mass balance calculations aggregate them with the surface runoff component. The difference between the estimates is greatest following periods of high discharge in winter, implying that these transient stores of water
\end{abstract}

feed the river for several weeks to months at that time. $\mathrm{Cl}$ vs. discharge variations during individual flow events also demonstrate that inflows of high-salinity older water occurs on the rising limbs of hydrographs followed by inflows of low-salinity water from the transient stores as discharge falls. The joint use of complementary techniques allows a better understanding of the different components of water that contribute to river flow, which is important for the management and protection of water resources.

\section{Introduction}

Documenting the sources of water in rivers and streams is critical to our understanding of hydrological processes and for the management of groundwater and surface water resources (e.g. Yu and Schwartz, 1999; Uhlenbrook et al., 2002; Eckhardt, 2005; Gonzales et al., 2009; Kirchner, 2009; Sanford et al., 2012). If rivers receive substantial groundwater inflows, groundwater extraction may significantly reduce river flow during periods of low rainfall with consequent impacts on riverine ecosystems or the utility of surface water resources. Managing surface water and groundwater resources thus requires a sound knowledge of the likely quantities of groundwater that rivers receive. Understanding the relative contributions of groundwater and surface water to river discharge is also important to assessing potential impacts of climate change and for flood forecasting (Winter, 1999, 2000). While it is well understood that groundwater and surface water systems interact, it is difficult to robustly measure 
the fluxes of groundwater to gaining streams (Winter, 1999, 2000; Sophocleous, 2002).

River discharge following a rainfall event may be divided into quickflow (water that contributes to river flow soon after the rainfall event) and baseflow (water with longer residence times in the catchment that sustains the river between rainfall events) (e.g. Hall, 1968; Nathan and McMahon, 1990; Yu and Schwartz, 1999; Eckhardt, 2005; Brodie et al., 2007). As discussed by Hall (1968), Brodie et al. (2007), and Schwartz (2007) these two components may include water from several sources. The quickflow component will include event water but can also include older water displaced from soils and the unsaturated zone, groundwater mobilised by hydraulic loading due to recharge on the floodplains or groundwater displaced from perched aquifers (Sklash and Farvolden, 1979; Rice and Hornberger, 1998; Anderson and Burt, 1980; Wittenberg and Sivapalan, 1999; Kirchner, 2009; Hrachowitz et al., 2011; Zabaleta and Antiguedad, 2013). In gaining river systems, baseflow will include inputs from regional groundwater but may also include interflow, the return of water from bank storage, or draining of pools on the floodplain (Chen et al., 2006; McCallum et al., 2010; Hrachowitz et al., 2011), and these components may change in importance at different times of the hydrological cycle or during wet or dry years (Aubert et al., 2012). The potential presence of multiple sources of water contributing to both the baseflow and quickflow components complicates our understanding of groundwater-surface water interaction.

Many techniques have been applied to quantify the water balance in rivers (e.g. Winter, 1999; Sophocleous, 2002; Brodie et al., 2007; Schwartz, 2007; Stewart et al., 2007; Sanford et al., 2012; Cook, 2013). River discharge records represent the most comprehensive and abundant surface water datasets available. Commonly discharge is recorded at sub-daily to daily intervals at one or more gauges in a catchment, and records may extend for several decades or longer. Several techniques - such as graphical separation, rainfallrunoff models, and baseflow filters - have arisen to estimate baseflow fluxes from discharge records (e.g. Nathan and McMahon, 1990; Dye and Croke, 2003; Eckhardt, 2005, 2008; Brodie et al., 2007; Aksoy et al., 2009). Automated graphical baseflow separation algorithms such as fixed block, sliding block, or local minimum methods define baseflow as the minimum discharge over a given period of time, the duration of which is governed by catchment size (e.g. Sloto and Crouse, 1996; Aksoy et al., 2009). Digital filtering techniques assume that baseflow has a longer wavelength response than quickflow and may be estimated by passing a low-pass digital filter across the river hydrograph (e.g. Nathan and McMahon, 1990; Eckhardt, 2005). While these techniques are relatively simply applied and can be automated, there remains a degree of subjectivity (e.g. a range of digital filters exist). Some of the digital filters are tuneable so that estimates of baseflow fluxes can be brought into agreement with those from other techniques where catchment-specific knowledge exists (Eckhardt, 2005). The estimates of baseflow fluxes yielded by these techniques include all delayed water, not just groundwater inflows (Nathan and McMahon, 1990; Brodie et al., 2007).

There is an increasing volume of river geochemistry data. This includes electrical conductivity (EC), major ions, stable and radiogenic isotopes, gases, nutrients, and contaminants. Provided that groundwater and surface water have different concentrations of a given chemical component and the behaviour of that component is well known (e.g. whether it behaves conservatively and any rates of degassing or decay), variations in river geochemistry may be used to estimate groundwater inflows to rivers (e.g. Rice and Hornberger, 1998; Stewart et al., 2007; Gonzalez et al., 2009; Sanford et al., 2012; Cartwright et al., 2011; Hrachowitz et al., 2011; Cook, 2013). Given that some delayed sources of water such as bank storage are likely to be geochemically similar to the surface water from which they are derived, chemical mass balances may yield estimates of groundwater inflows rather than the total baseflow flux (McCallum et al., 2010). During single flow events there may be also different concentration vs. discharge relationships on the rising limb of the hydrograph compared with the falling limb (Evans and Davies, 1998; Hornberger et al., 2001; Aubert et al., 2012). Such hysteresis loops have been used to assess how sources of water supplying the river vary over time.

Many geochemical studies of baseflow represent surveys along rivers at specific times, often at low-flow conditions (e.g. Mullinger et al., 2007; Cartwright et al., 2011; Cook, 2013). Thus while they constrain the spatial variability of groundwater inflows and fluxes, they commonly do not constrain temporal variability. By contrast, many calculations of baseflow fluxes based on river discharge use daily or subdaily data from a single gauge. This approach captures the temporal variations but aggregates the behaviour of the entire catchment upstream of the gauge. Some studies have used time series of geochemical data; however, these are commonly collected over short time periods (e.g. Evans and Davies, 1998; Yu and Schwartz, 1999; Gonzales et al., 2009; Hrachowitz et al., 2011) or at relatively long intervals (e.g. Ahearn et al., 2004; Aubert et al., 2012). Although EC is only a general indicator of water chemistry, it can be measured continuously on timescales comparable to those of river discharge. This allows a continuous record of chemical variation in the river to be established, which in turn permits a direct comparison between geochemical methods of estimating baseflow fluxes and those based on the discharge hydrographs.

\section{Objectives}

The objectives of this paper are to contrast baseflow fluxes estimated from the discharge hydrographs using graphical and filter techniques (herein termed analytical techniques) with those estimated by chemical mass balance using 
calculated $\mathrm{Cl}$ concentrations in the upper Barwon River, southeast Australia (Fig. 1). In part the choice of techniques is pragmatic. The absence of time series data for stable isotopes or major ions in rainfall precludes using techniques based on comparing the geochemistry of catchment outflows with that of rainfall (e.g. Kirchner, 2009; Hrachowitz et al., 2013). Additionally, lack of detailed soil moisture data or information about unsaturated zone flow (and the relatively large size of the catchment) makes application of rainfall-runoff models (e.g. Dye and Croke, 2003) difficult. The data available in the Barwon catchment are similar to those in many catchments globally, and the adopted techniques have been applied individually or in combination elsewhere (e.g. Nathan and McMahon, 1990; Yu and Schwartz, 1999; Eckhardt, 2005; Stewart et al., 2007; Gonzalez et al., 2009; Aksoy et al., 2009; Sanford et al., 2012; Zabaleta and Antiguedad, 2013). For management purposes, it is important to understand the water balance in medium or larger catchments, recognising that they will rarely have the data density of small heavily instrumented catchments.

Other studies have used a similar comparison between techniques to calibrate one method or another of estimating baseflow; for example, Stewart et al. (2007) and Gonzeles et al. (2009) used chemical mass balance to calibrate graphical separation and filter techniques, respectively. However, here we use the comparison of baseflow fluxes at different flow conditions to assess specifically whether there are different water stores that contribute to baseflow. Understanding the contribution of different water sources to rivers at different times will aid in the management of connected groundwater and surface water systems.

\section{Local geology and hydrogeology}

The Barwon River catchment occupies $\sim 2700 \mathrm{~km}^{2}$ of southern Victoria, Australia (Fig. 1) and includes three major river systems: the Barwon, Leigh, and Moorabool rivers (Corangamite Catchment Management Authority, 2005). This study focuses on the upper catchment of the Barwon River upstream of the Winchelsea gauging station (Fig. 1). The Barwon region has a temperate climate with annual rainfall varying from $\sim 1030 \mathrm{~mm}$ at Forrest to $\sim 630 \mathrm{~mm}$ at Winchelsea. Annual potential evapotranspiration in the upper Barwon catchment is 1000 to $1100 \mathrm{~mm} \mathrm{yr}^{-1}$, and potential evapotranspiration rates exceed average rainfall for the period between November and May (Bureau of Meteorology, 2012). On average 50 to $60 \%$ of the annual rainfall is received in the austral winter between July and October; January and February typically each receive 0 to $5 \%$ of the annual rainfall (Bureau of Meteorology, 2012). The variation in evapotranspiration and rainfall leads to a strong seasonality of flows in the Barwon River with a period of low discharge in late summer (generally between February and April) and a

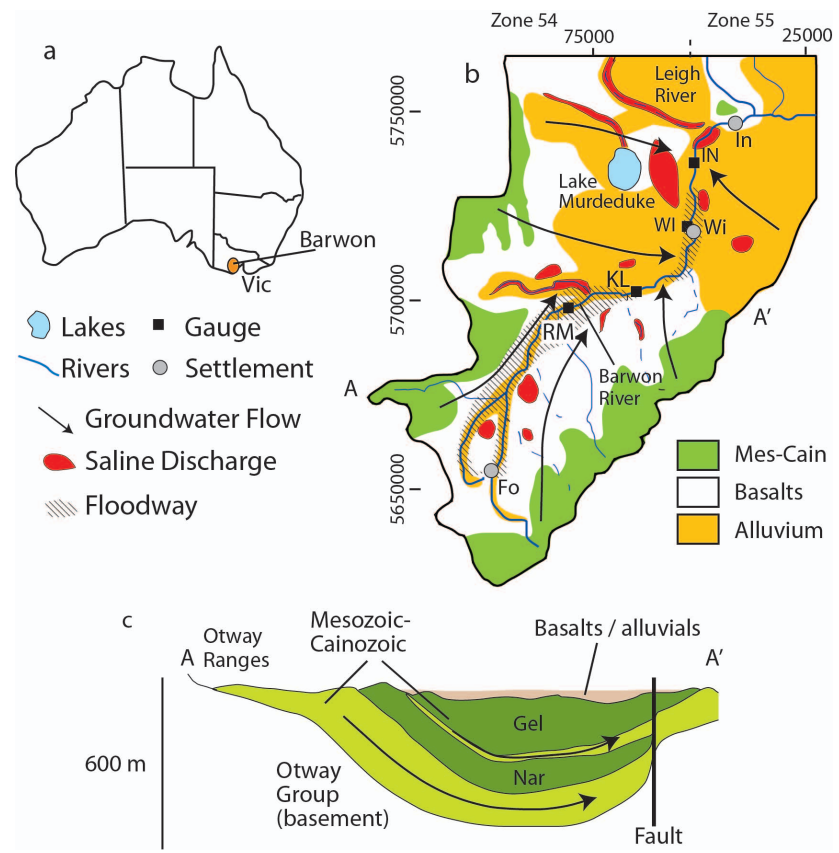

Fig. 1. (a) Location of upper Barwon catchment in Australia (Vic=Victoria). (b) Hydrology of the upper Barwon catchment showing simplified geology (Mes-Cain=Mesozoic Cainozoic sediments), groundwater flow directions, location of gauges $(\mathrm{IN}=$ Inverleigh; $\mathrm{KL}=$ Kildean Lane; $\mathrm{RM}=$ Ricketts Marsh; WI = Winchelsea), saline discharge sites, and settlements $(\mathrm{Fo}=$ Forrest In = Inverleigh; $\mathrm{Wi}=$ Winchelsea $)$. $($ c) Section across the upper Barwon catchment $-\mathrm{A}-\mathrm{A}^{\prime}$ in (a) - showing the broad geological structure. Mesozoic-Cainozoic aquifers shown in light green, aquitards $(\mathrm{Gel}=$ Gellibrand Marl; Nar = Narrawatuk Marl $)$ in dark green. Data from Witebsky et al. (1995), Corangamite Catchment Management Authority (2005), and Water Resources Data Warehouse (2012).

period of higher flows in winter (generally between June and October).

The headwaters of the Barwon River drain the northern slopes of the Otway Ranges where the surface geology comprises Mesozoic-Cainozoic sediments (Witebsky et al., 1995; Corangamite Catchment Management Authority, 2005; Dahlhaus et al., 2008). The remainder of the upper catchment comprises basaltic flows and pyroclastic deposits of the Piocene-Pleistocene Newer Volcanics Province that are interbedded with Tertiary marine and freshwater sediments. Holocene alluvial deposits are developed along the river courses.

The headwaters of the Barwon River largely comprises native eucalypt forest and plantation forestry; however much of the upper catchment has been cleared for sheep and cattle grazing and broad-acre agriculture. The basalts and alluvial sediments have mainly sandy loam soils that are typically $2-5 \mathrm{~m}$ deep and which are moderately well drained (Corangamite Catchment Management Authority, 2005). Except for the headwaters, slope angles are low $(<10 \%)$ and 
the majority of the catchment comprises a broad gently undulating floodplain that is several kilometres wide and into which the Barwon river is incised to depths of up to $4 \mathrm{~m}$. There are abundant pools and marshes that occupy depressions in the relatively young volcanic landscape. These together with bank storage (the river is commonly incised to 2-3 m below its floodplain) probably form the dominant transient water stores, although interflow and soil drainage will also occur.

The Mesozoic-Cainozoic sediments form a sequence of aquifers and aquitards that is up to $400 \mathrm{~m}$ thick. These sediments overlie the Jurassic-Cretaceous Otway Group, which forms the regional basement (Fig. 1c). Groundwater in the Mesozoic-Cainozoic aquifers flows from the recharge area in the Otway Ranges to the northeast (Witebsky et al., 1995; Petrides and Cartwright, 2006). Over much of the catchment, this deeper groundwater is separated from near-surface aquifers by the thick Gellibrand and Narrawatuk marls that act as aquitards (Fig. 1c). On the floodplain the groundwater with which the Barwon River interacts is that in the basalt and alluvial sediments (Witebsky et al., 1995). Groundwater flow in the shallower basaltic and alluvial aquifers is also to the northeast (Fig. 1b). Water table depths vary from several metres on the valley sides to typically $<5$ m over much of the floodplain (Corangamite Catchment Management Authority, 2005; Dahlhaus et al., 2008). Annual variations in groundwater elevations in shallow bores on the floodplain are typically 1-3 $\mathrm{m}$, with higher elevations recorded in the later parts of the year following recharge by winter rains (Water Resources Data Warehouse, 2012; Department of Primary Industries, unpublished data). The upper Barwon River is perennial and receives groundwater inflows from the basalt and alluvial sediments along much of its length (Corangamite Catchment Management Authority, 2005; Witebsky et al., 1995; Cartwright et al., 2013)

The $\mathrm{Cl}$ concentration of groundwater in the shallow aquifers ranges from 250 to $15000 \mathrm{mg} \mathrm{L}^{-1}$ and generally increases down catchment (Witebsky et al., 1995; Petrides and Cartwright, 2006; Water Resources Data Warehouse, 2012). There are several instances of shallow $(<10 \mathrm{~m})$ groundwater with much higher salinities $(\mathrm{Cl}$ concentrations up to $30000 \mathrm{mg} \mathrm{L}^{-1}$ ) in low-lying regions on the river floodplains (Fig. 1). The high groundwater salinities in this area and throughout the Newer Volcanics Province in general result from two causes (e.g. Bennetts et al., 2006; Dahlhaus et al., 2008; Cartwright et al., 2009; Tweed et al., 2011). Firstly, poorly drained largely endorheic saline lakes, wetlands and marshes developed on the irregular surface of the lava flows act as local recharge points. Secondly, as is the case through much of southeast Australia, the combination of low rainfall, subdued topography, and water-efficient native vegetation leads to high evapotranspiration rates that produce saline groundwater. Due to its high salinity, shallow groundwater is generally not utilised in this catchment.

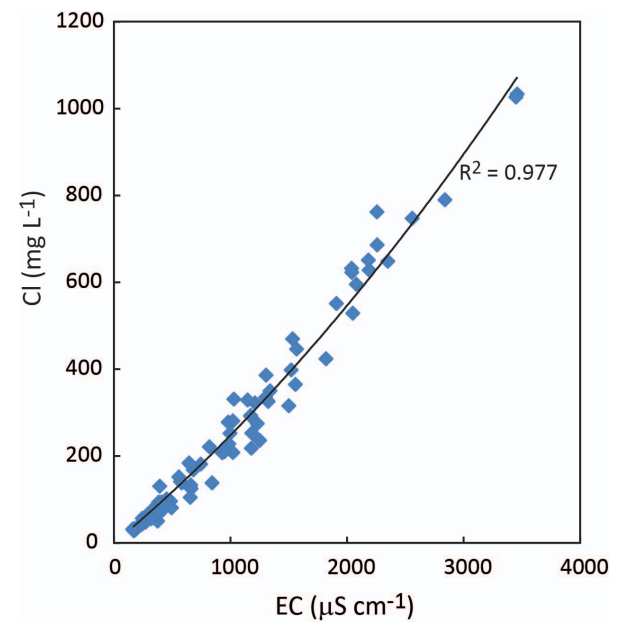

Fig. 2. Correlation between $\mathrm{EC}$ and $\mathrm{Cl}$ in the Barwon River. Data from Water Resources Data Warehouse (2012) and Cartwright et al. (2013).

Total annual discharges of the upper Barwon River between 1974 and 2011 were between $2.3 \times 10^{6}$ and $3.3 \times 10^{8} \mathrm{~m}^{3} \mathrm{yr}^{-1}$ (Water Resources Data Warehouse, 2012). During flood events the discharge increases significantly between stations, implying that the kinematic effects on the hydrographs are small. $\mathrm{Cl}$ concentrations of the Barwon River at Forrest in the uppermost catchment are typically $<100 \mathrm{mg} \mathrm{L}^{-1}$, whereas $\mathrm{Cl}$ concentrations at Winchelsea are up to $1250 \mathrm{mg} \mathrm{L}^{-1}$ (Water Resources Data Warehouse, 2012). This increase in salinity along the Barwon River is largely due to the influxes of saline groundwater (Corangamite Catchment Management Authority, 2005).

\section{Methodology and data sources}

River discharge, groundwater geochemistry, and river geochemistry data are from the Victoria Water Resources Data Warehouse (2012), Cartwright et al. (2013), and unpublished Department of Primary Industries data. River EC and discharge are monitored continuously on a sub-daily basis (typically 30 to $60 \mathrm{~min}$ ) at several sites in the Barwon River, and EC records extend from 1989 for some gauges to 2012. Measurements of $\mathrm{EC}$ values and $\mathrm{Cl}$ concentrations have also been made across a wide range of river flows, including very low flow and high-flow conditions, and these parameters are very well correlated $\left(R^{2}=0.98\right)$ (Fig. 2$)$. This allows $\mathrm{Cl}$ concentrations to be estimated robustly from the EC data. Estimation of the baseflow fluxes from the stream hydrograph and calculated $\mathrm{Cl}$ concentrations used the following methods.

\subsection{Local minimum method}

In the local minimum graphical method the baseflow flux is assumed to vary linearly between minimum discharges 
that occur within a window of a specified number of days $\left(0.5\left[2 N^{*}-1\right]\right)$ (Sloto and Crouse, 1996; Askoy et al., 2009). The number of days after which surface water runoff ceases $(N)$ scales to catchment area, and the empirical relationship $N=A^{0.2}$ is generally adopted, where $A$ is area in square miles (Sloto and Crouse, 1996); $2 N^{*}$ is the odd integer nearest to $2 N$

\subsection{Digital filters}

Digital filters estimate baseflow influxes by removing the high-frequency quickflow signal from the hydrograph to discern the longer wavelength baseflow. Two commonly applied filters were used in this study:

$b_{k}=a b_{k-1}+\frac{1+a}{2}\left(y_{k}-y_{k-1}\right)$

(Lyne and Hollick, 1979; Nathan and McMahon, 1990) and

$b_{k}=\frac{\left(1-\mathrm{BFI}_{\max }\right) a b_{k-1}+(1-a) \mathrm{BFI}_{\max } y_{k}}{1-a \mathrm{BFI}_{\max }}$

(Eckhardt, 2005, 2008). While there are other possible digital filters (e.g. the Schwartz, 2007, filter that takes into account differences in baseflow fluxes on the rising and falling limbs of the hydrographs), the chosen two are readily implemented. In Eqs. (1) and (2), $b_{k}$ is the baseflow flux on day $k, y_{k}$ is total discharge on day $k$, and $a$ is the recession constant that is estimated from the recession limbs of the hydrographs by calculating $y_{k+1}=a y_{k}$ for every stream discharge value that is part of a recession period of at least five days (Nathan and McMahon, 1990; Eckhardt, 2005, 2008). In the Eckhardt filter, $\mathrm{BFI}_{\max }$ is the maximum value of the baseflow index (the long-term ratio of baseflow to river discharge) that can be modelled by the algorithm.

\subsection{Chemical mass balance}

Where concentrations of a specific chemical component in groundwater are significantly different to those in surface water, baseflow fluxes may be estimated via

$b_{k}=y_{k} \frac{C_{\mathrm{r}}-C_{\mathrm{sw}}}{C_{\mathrm{gw}}-C_{\mathrm{sw}}}$

(Yu and Schwartz, 1999), where $C_{\mathrm{r}}, C_{\mathrm{sw}}$, and $C_{\mathrm{gw}}$ are the concentrations of the component in the river, surface runoff, and groundwater, respectively.

\section{Discharge and Cl variation}

This study analyses variations in discharge and $\mathrm{Cl}$ concentrations between 2001 and 2011, which represents the length of the EC record at the Winchelsea gauge from which the $\mathrm{Cl}$ concentrations were calculated (Fig. 2). Although a longer flow and EC record (from 1989) exists for the Inverleigh gauge (Fig. 1), the inflows of anomalously saline groundwater $\left(\mathrm{Cl}\right.$ concentrations up to $\left.25000 \mathrm{mg} \mathrm{L}^{-1}\right)$ in the region between the Winchelsea and Inverleigh gauges (Corangamite Catchment Management Authority, 2005) may complicate the results of chemical mass balance techniques.

Average rainfall at Winchelsea between 2001 and 2011 was $652 \mathrm{~mm} \mathrm{yr}^{-1}$, which is close to the long-term (1904 to 2011) average of $630 \mathrm{~mm} \mathrm{yr}^{-1}$ (Bureau of Meteorology, 2012). This period comprises a number of years of belowaverage rainfall (notably 2006 to 2009) that occurred during a regional drought period in southeast Australia together with years of above-average rainfall (e.g. 2001 and 2010 to 2011). Annual river discharge at Winchelsea between 2001 and 2011 ranged from $8.14 \times 10^{6}$ to $1.26 \times 10^{8} \mathrm{~m}^{3} \mathrm{yr}^{-1}$ with a total discharge over this period of $5.37 \times 10^{8} \mathrm{~m}^{3}$ (Table 1 ). There are periods of no discharge, notably in December 2006 to February 2007 and February to April 2009. These time periods represent the summers of low-rainfall years when several of the gauges in the Barwon and adjacent rivers also recorded no or very little discharge (Water Resources Data Warehouse, 2012). This indicates that the river had ceased flowing rather than the data reflecting malfunctioning of the gauge.

Years 2001, 2002, and 2006 will be used to illustrate the patterns of flow and $\mathrm{Cl}$ variation (Figs. 3-5). The year 2001 had the highest annual discharge in this period, 2002 represents a year where the discharge in the upper Barwon River was close to the long-term median value (albeit with a protracted period of low discharge during a dry summer in early 2002), and 2006 is the year with lowest discharge between 2001 and 2011. Rainfall in 2001, 2002, and 2006 was 807,654 , and $428 \mathrm{~mm} \mathrm{yr}^{-1}$, respectively. The maximum discharge between 2001 and 2011 was $7.32 \times 10^{6} \mathrm{~m}^{3} \mathrm{day}^{-1}$ and the median discharge $\left(Q_{50}\right)$ was $2.16 \times 10^{4} \mathrm{~m}^{3} \mathrm{day}^{-1}$ (Fig. 6). The maximum and median daily discharges are $7.32 \times 10^{6}$ and $91.6 \times 10^{4} \mathrm{~m}^{3}$ day $^{-1}$ in $2001,1.13 \times 10^{6}$ and $3.32 \times 10^{6} \mathrm{~m}^{3} \mathrm{day}^{-1}$ in 2002 , and $1.01 \times 10^{6}$ and $7.9 \times 10^{3} \mathrm{~m}^{3} \mathrm{day}^{-1}$ in 2006 (Fig. 6). The discharge at Winchelsea in 2002 varied between $1.97 \times 10^{3}$ and $1.13 \times 10^{7} \mathrm{~m}^{3} \mathrm{day}^{-1}$, with a total discharge for the year of $3.96 \times 10^{7} \mathrm{~m}^{3} \mathrm{yr}^{-1}$ (Table 1; Figs. 4 and 7). Higher discharges occurred during a discrete flow event in February and a series of high-flow events between June and October. River discharges were lowest in March to April but remained generally high $\left(>10^{5} \mathrm{~m}^{3} \mathrm{day}^{-1}\right)$ between the flow events in June to October. The discharge variations in 2001 and 2006 are similar (Figs. 3 and 5).

Calculated $\mathrm{Cl}$ concentrations in the Barwon River in 2001 to 2011 were between 23 and $1250 \mathrm{mg} \mathrm{L}^{-1}$ (Fig. 7). During the peak of the discharge events the river has low $\mathrm{Cl}$ concentrations, implying that it is fed largely by surface runoff or low-salinity water displaced from near-surface stores at those times. $\mathrm{Cl}$ concentrations $>1000 \mathrm{mg} \mathrm{L}^{-1}$ are mainly recorded during periods of very low or no discharge and probably reflect evaporation when the river is stagnant. For 


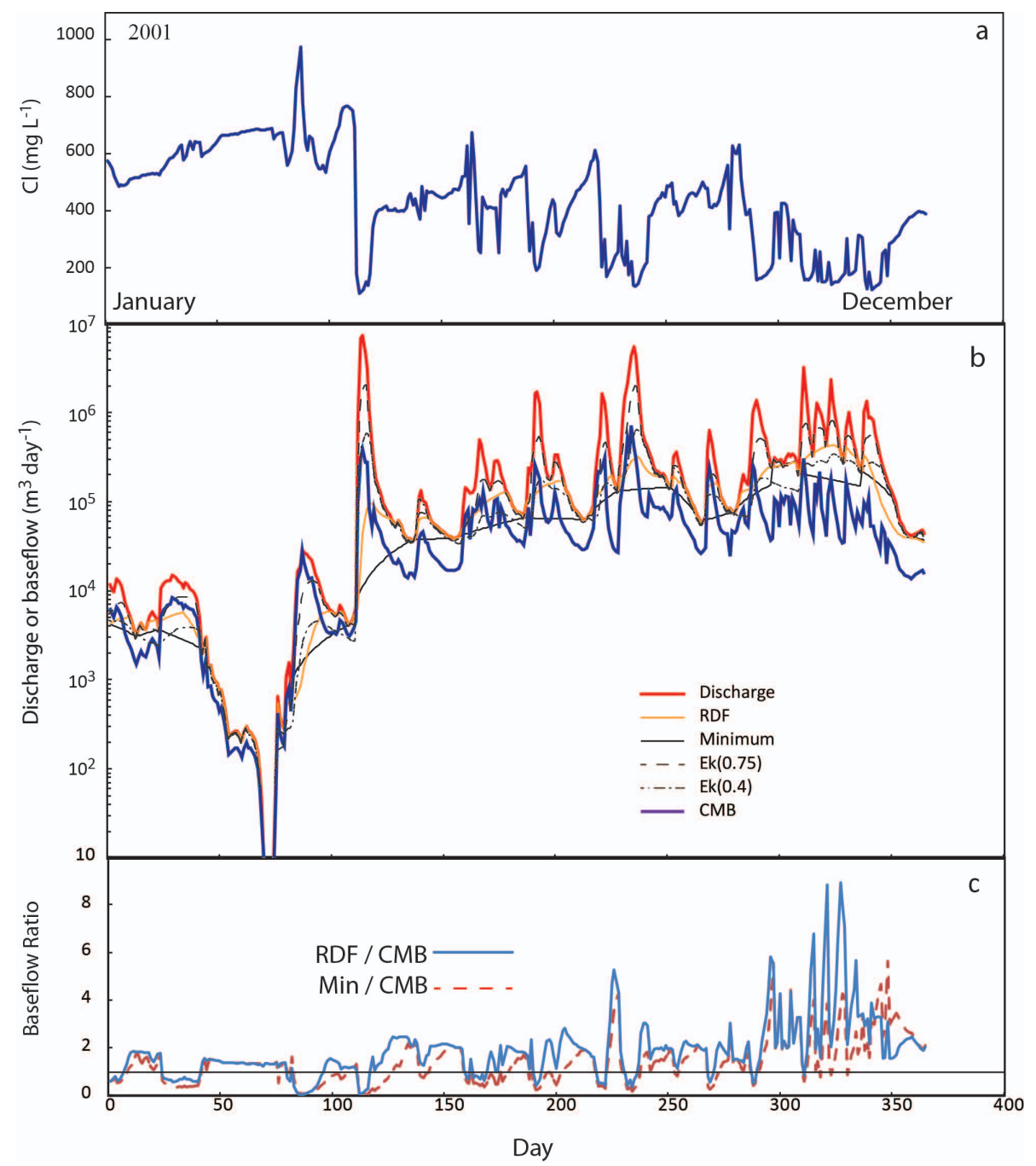

Fig. 3. (a) Variation in $\mathrm{Cl}$ concentrations in the upper Barwon River at Winchelsea in 2001. (b) Variation in discharge of the Barwon River at Winchelsea in 2001 and estimated baseflow calculated by the Nathan and McMahon (1990) implementation of the Lyne and Hollick (1979) digital filter (RDF), local minimum (Sloto and Crouse, 1996) (Min), the Ekchardt (2005) digital filter with BFI $\max =0.75(\mathrm{Ek}(0.75)$ ) and 0.4 (Ek(0.4)), and chemical mass balance (CMB). (c) Ratio of baseflows derived by smoothed minimum and the Lyne and Hollock (1979) digital filter to that estimated by chemical mass balance. Days are from 1 January. Data from Water Resources Data Warehouse (2012).

the majority of the monitoring period $\mathrm{Cl}$ concentrations are $<1000 \mathrm{mg} \mathrm{L}^{-1}$ (Fig. 7). In 2002, Cl concentrations were highest (up to $820 \mathrm{mg} \mathrm{L}^{-1}$ ) during the March to April lowflow period and were generally $<550 \mathrm{mg} \mathrm{L}^{-1}$ throughout June to October, even during periods of low flow. The variation in discharge and $\mathrm{Cl}$ concentrations for 2001 and 2006 are similar.

While $\mathrm{Cl}$ concentrations are broadly inversely correlated with discharge (Fig. 7), $\mathrm{Cl}$ vs. discharge variations for several of the major flow events in 2002 define clockwise hysteresis loops (i.e. $\mathrm{Cl}$ concentrations are lower at any given discharge on the falling limb of the hydrograph than on the rising limb) (Fig. 8). For the event between days 170 and 200 in 2002 (number 2 on Fig. 4), gauges elsewhere in the catchment
(Kildean Lane, Ricketts Marsh, and Inverleigh) record similar clockwise hysteresis loops (Fig. 9).

\section{Estimating baseflow}

\subsection{Graphical separation techniques}

The local minimum graphical method of Sloto and Crouse (1996) and Askoy et al. (2009) was applied to the hydrograph data from the Winchelsea gauge; the catchment area at this gauge $(A)$ is $1270 \mathrm{~km}^{2}\left(490 \mathrm{~m}^{2}\right)$, yielding $2 N^{*}=7$. The analysis of the hydrograph was completed between the minimum discharges proceeding January 2001 and following December 2011 to allow baseflow fluxes 


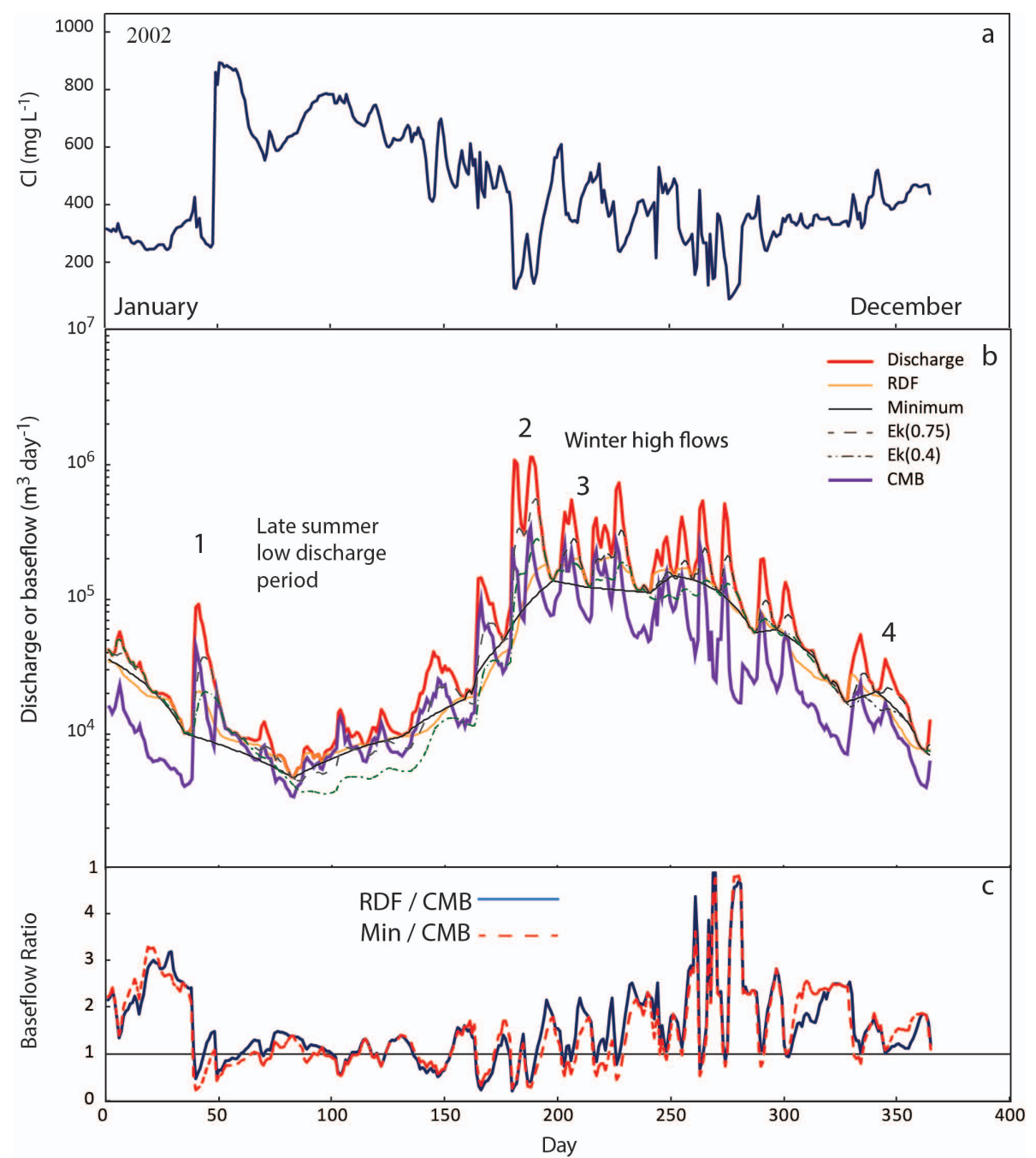

Fig. 4. (a) Variation in $\mathrm{Cl}$ concentrations in the upper Barwon River at Winchelsea in 2002. (b) Variation in discharge of the Barwon River at Winchelsea in 2002 and estimated baseflow calculated by the Nathan and McMahon (1990) implementation of the Lyne and Hollick (1979) digital filter (RDF), local minimum (Sloto and Crouse, 1996) (Min), the Ekchardt (2005) digital filter with BFI $\mathrm{I}_{\max }=0.75(\mathrm{Ek}(0.75)$ ) and 0.4 (Ek(0.4)), and chemical mass balance (CMB). (c) Ratio of baseflows derived by local minimum and the Lyne and Hollock (1979) digital filter to that estimated by chemical mass balance. Days are from 1 January. Data from Water Resources Data Warehouse (2012).

for the entire 2001 to 2011 period to be calculated. For 2001, 2002, and 2011 the local minimum technique predicts that baseflow fluxes are close to total discharge during the March to April low-flow periods that correspond to the low-rainfall period at the end of summer (Figs. 3-5). Baseflow fluxes increase during the higher-discharge periods of July to October, which probably reflects hydraulic loading on the floodplain. Groundwater elevations in shallow bores rise by up to $3 \mathrm{~m}$ following winter rains (Victorian Water Resources Data Warehouse, 2012; Department of Primary Industries, unpublished data), and this increase in heads will result in greater groundwater flow towards the river. For 2001, 2002, and 2006 the baseflow fluxes estimated by this technique were $2.5 \times 10^{7} \mathrm{~m}^{3} \mathrm{yr}^{-1}(20 \%$ of total discharge), $1.8 \times 10^{7} \mathrm{~m}^{3} \mathrm{yr}^{-1}$, (44\% of total discharge), and $3.2 \times 10^{6} \mathrm{~m}^{3} \mathrm{yr}^{-1}$ (39\% of total discharge), respectively. For the period between 2001 and 2011 the local minimum technique yields a total baseflow volume of $1.4 \times 10^{8} \mathrm{~m}^{3}$ ( $\sim 26 \%$ of the volume of water discharged by the upper Barwon River) (Table 1). The graphical technique used here is an empirical technique and it is difficult to assign an error to the results. Varying the $N$ does have some impact as it increases or decreases the number local minimum discharge points. Increasing $2 N^{*}$ to 9 reduces the estimate of baseflow between 2001 and 2011 by $\sim 10 \%$, whereas reducing $2 N^{*}$ to 5 results in a $\sim 12 \%$ increase in baseflow over this time period. 


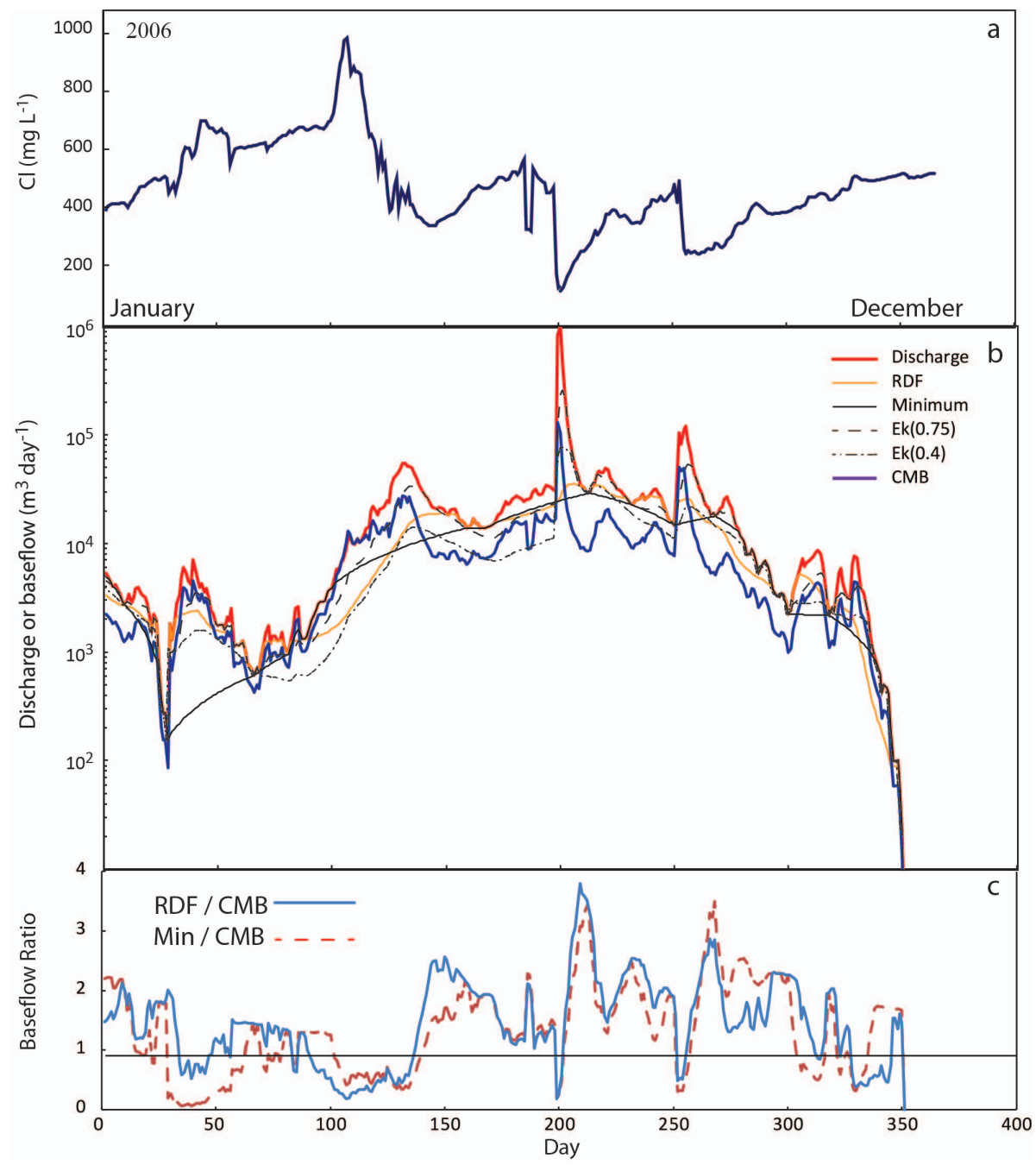

Fig. 5. (a) Variation in $\mathrm{Cl}$ concentrations in the upper Barwon River at Winchelsea in 2006. (b) Variation in discharge of the Barwon River at Winchelsea in 2001 and estimated baseflow calculated by the Nathan and McMahon (1990) implementation of the Lyne and Hollick (1979) digital filter (RDF), local minimum (Sloto and Crouse, 1996) (Min), the Ekchardt (2005) digital filter with BFI $\mathrm{max}_{\max }=0.75(\mathrm{Ek}(0.75))$ and 0.4 (Ek(0.4)), and chemical mass balance (CMB). (c) Ratio of baseflows derived by local minimum and the Lyne and Hollick (1979) digital filter to that estimated by chemical mass balance. Days are from 1 January. Data from Water Resources Data Warehouse (2012).

\subsection{Digital filters}

The Lyne and Hollick filter was applied to the Winchelsea discharge data in three passes (forward, backwards, forwards) as suggested by Nathan and McMahon (1990). The Eckhardt filter was applied in a single pass (c.f. Eckhardt, $2005)$ to the same data. Both filters were applied with the condition that $b_{k} \leq y_{k}$. The value of $\mathrm{BFI}_{\max }$ in the Eckhardt filter is subjective; Eckhardt $(2005,2008)$ suggests values of 0.7 to 0.8 for perennial streams on porous aquifers and values as low as 0.2 to 0.25 for perennial streams on crystalline basement. In this study, given that the upper Barwon is a perennial river hosted within porous aquifers, an initial $\mathrm{BFI}_{\max }$ value of 0.75 was used. $a$ was estimated as 0.95 from the recession limbs of the hydrographs as described by Nathan and McMahon (1990).

The Lyne and Hollick filter produces a predicted variation in baseflow fluxes that is similar to that of the local minimum method (Figs. 3-5; Table 1). The overall baseflow flux calculated using this method for 2001, 2002 , and 2006 is $3.8 \times 10^{7} \mathrm{~m}^{3} \mathrm{yr}^{-1}$ (30\% of total discharge), $2.1 \times 10^{7} \mathrm{~m}^{3} \mathrm{yr}^{-1}$ (52\% of the total discharge), and $3.6 \times 10^{6} \mathrm{~m}^{3} \mathrm{yr}^{-1}$ (44\% of total discharge), respectively. For the period between 2001 and 2011 this filter yields a net volume of baseflow of $1.9 \times 10^{8} \mathrm{~m}^{3}(\sim 35 \%$ of the total volume of water discharged by the upper Barwon River) (Table 1). As with the graphical separation techniques it is difficult to assign an error to the results of the Lyne and Hollick filter. The results are relatively insensitive to the value of $a$, which 
Table 1. Summary of baseflow estimates for the upper Barwon River.

\begin{tabular}{|c|c|c|c|c|c|c|}
\hline & \multirow{2}{*}{$\begin{array}{l}\text { Discharge } \\
\left(\times 10^{7} \mathrm{~m}^{3} \mathrm{yr}^{-1}\right)\end{array}$} & \multicolumn{5}{|c|}{ Baseflow fluxes $\left(\times 10^{7} \mathrm{~m}^{3}\right)$} \\
\hline & & $\operatorname{Min}^{\mathrm{a}}$ & $\mathrm{RDF}^{\mathrm{b}}$ & $\operatorname{Ek}(0.4)^{\mathrm{c}}$ & $\operatorname{Ek}(0.75)^{\mathrm{d}}$ & $\mathrm{CMB}^{\mathrm{e}}$ \\
\hline 2001 & 12.6 & 2.5 & 3.8 & 4.1 & 7.1 & 1.5 \\
\hline$\%^{\mathrm{h}}$ & & 20 & 30 & 32 & 56 & 12 \\
\hline 2002 & 3.96 & 1.8 & 2.1 & 1.6 & 2.7 & 0.99 \\
\hline$\%$ & & 44 & 52 & 42 & 69 & 25 \\
\hline 2003 & 6.46 & 1.6 & 2.4 & 2.2 & 3.9 & 1.2 \\
\hline$\%$ & & 24 & 37 & 39 & 61 & 19 \\
\hline 2004 & 5.80 & 2.2 & 2.4 & 2.2 & 3.6 & 0.90 \\
\hline$\%$ & & 39 & 42 & 39 & 63 & 16 \\
\hline 2005 & 3.36 & 1.1 & 1.3 & 1.1 & 2.0 & 0.60 \\
\hline$\%$ & & 32 & 39 & 32 & 60 & 18 \\
\hline 2006 & 0.814 & 0.32 & 0.36 & 0.31 & 1.8 & 0.18 \\
\hline$\%$ & & 39 & 44 & 39 & 64 & 22 \\
\hline 2007 & 3.85 & 0.50 & 0.73 & 0.98 & 1.9 & 4.8 \\
\hline$\%$ & & 16 & 19 & 25 & 48 & 12 \\
\hline 2008 & 0.889 & 0.40 & 0.41 & 0.34 & 0.62 & 2.3 \\
\hline$\%$ & & 45 & 46 & 39 & 70 & 25 \\
\hline 2009 & 2.71 & 0.69 & 1.0 & 0.98 & 1.7 & 0.53 \\
\hline$\%$ & & 25 & 37 & 36 & 63 & 20 \\
\hline 2010 & 7.30 & 2.1 & 2.5 & 2.1 & 4.5 & 1.1 \\
\hline$\%$ & & 29 & 34 & 36 & 61 & 15 \\
\hline 2011 & 3.88 & 0.89 & 1.3 & 1.4 & 2.3 & 0.69 \\
\hline$\%$ & & 23 & 33 & 37 & 60 & 18 \\
\hline \multirow[t]{2}{*}{ Total $^{\mathrm{g}}$} & Discharge & \multicolumn{5}{|c|}{ Total baseflow volumes $\left(\times 10^{7} \mathrm{~m}^{3}\right)$} \\
\hline & $\left(\times 10^{7} \mathrm{~m}^{3}\right)$ & Min & $\mathrm{RDF}$ & $\mathrm{Ek}(0.4)$ & $\mathrm{Ek}(0.75)$ & $\mathrm{CMB}$ \\
\hline 2001-2011 & 53.7 & 14 & 19 & 19 & 32 & 8.8 \\
\hline$\%$ & & 26 & 35 & 35 & 59 & 16 \\
\hline
\end{tabular}

a Local minimum (Sloto and Crouse, 1996); ${ }^{\mathrm{b}}$ Nathan and McMahon (1990) implementation of the Lyne and Hollick (1979) recursive digital filter; ${ }^{\mathrm{c}}$ Ekchardt (2005) digital filter with $\mathrm{BFI}_{\max }=0.4 ;{ }^{\mathrm{d}}$ Ekchardt (2005) digital filter with $\mathrm{BFI}_{\max }=0.75 ;{ }^{\mathrm{e}}$ chemical mass balance (Yu and Schwartz, 1999); ${ }^{\mathrm{f}}$ baseflow as a percent of total discharge; ${ }^{\mathrm{g}}$ total baseflow and discharge volumes between 2001 and 2011.

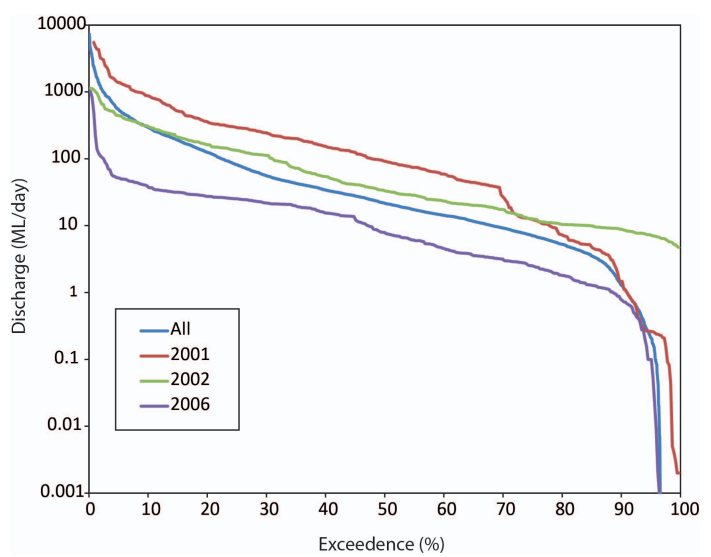

Fig. 6. Flow duration curve for the upper Barwon River in 2001, 2002, 2006, and for all years between 2001 and 2011. Data from Water Resources Data Warehouse (2012). is the one measurable value (Eckhardt, 2005). Reducing the number of passes of the filter would increase the baseflow estimates, but this is rarely done in applying this filter.

The estimated baseflow flux from the Eckhardt filter with $\mathrm{BFI}_{\text {max }}=0.75$ is significantly higher $\left(2.7 \times 10^{7} \mathrm{~m}^{3} \mathrm{yr}^{-1}\right.$ or $69 \%$ of total discharge in 2002) than that of the local minimum method or the Lyne and Hollick filter (Table 1, Figs. 35). The net baseflow volume between 2001 and 2011 using this filter is estimated as $3.2 \times 10^{8} \mathrm{~m}^{3}$, or $\sim 59 \%$ of the total of water discharged by the upper Barwon River (Table 1). The predicted variation in baseflow fluxes is also less attenuated, with higher baseflow fluxes during each of the high-flow events than estimated by the other analytical methods. Reducing $\mathrm{BFI}_{\max }$ to 0.4 results in more attenuated baseflow fluxes that are similar to those estimated by the Lyne and Hollick filter and the local minimum method (Figs. 3-5, Table 1). 


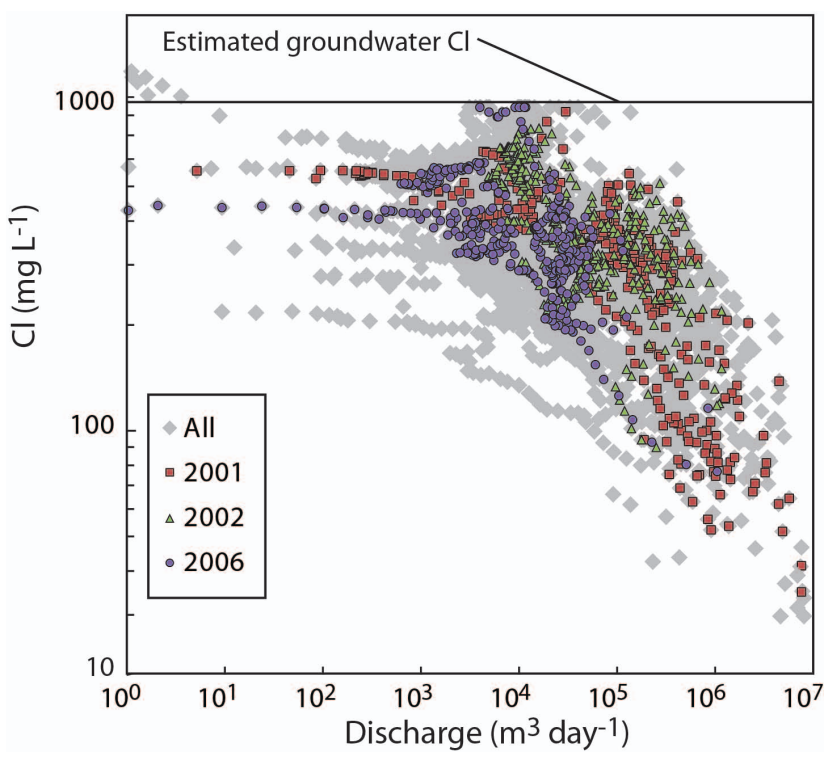

Fig. 7. $\mathrm{Cl}$ concentrations vs. discharge for the upper Barwon River between 2001 and 2011. Data from Water Resources Data Warehouse (2012).

\subsection{Chemical mass balance}

Baseflow influxes using chemical mass balance were estimated for the calculated river $\mathrm{Cl}$ concentrations at Winchelsea using Eq. (3). The mass balance calculations assume that the tracer behaves conservatively. Molar $\mathrm{Cl} / \mathrm{Br}$ ratios of the Barwon River are 520-830, $\mathrm{Cl} / \mathrm{Br}$ ratios of the soil water are 410-830, and those of groundwater are 540730 (Cartwright et al., 2013). These $\mathrm{Cl} / \mathrm{Br}$ ratios are similar to those of the oceans $(\sim 650)$ and coastal rainfall but are far lower than those expected from halite dissolution $\left(10^{4}-\right.$ $10^{5}$ ) (Davis et al., 1998); hence dissolution of halite does not increase $\mathrm{Cl}$ concentrations in the river, nor does it increase the salinity of groundwater or soil water. In-river evaporation may also increase $\mathrm{Cl}$ concentrations. $\delta^{18} \mathrm{O}$ and $\delta^{2} \mathrm{H}$ values of the Barwon River define evaporation trends, and there is commonly a downstream increase in $\delta^{18} \mathrm{O}$ values (Cartwright et al., 2013). However, the recorded shift in $\delta^{18} \mathrm{O}$ values of $<4 \%$ implies $<20 \%$ evaporation (c.f. Gonfiantini, 1986). Far greater degrees of evaporation would be required to increase the $\mathrm{Cl}$ concentrations from those of rainfall (typically $1.5 \mathrm{mg} \mathrm{L}^{-1}$ ) to those observed in the river. Overall, these data imply that the high $\mathrm{Cl}$ concentrations of the Barwon River reflect the inflows of shallow groundwater, water from saline wetlands, and/or water from the unsaturated zone rather than in-river evaporation.

The $\mathrm{Cl}$ concentrations of groundwater in the upper Barwon catchment range from 250 to $15000 \mathrm{mg} \mathrm{L}^{-1}$ with local occurrences of highly saline groundwater $(\mathrm{Cl}$ concentrations of up to $30000 \mathrm{~m} \mathrm{~L} \mathrm{~L}^{-1}$ ). However, the distribution of shallow groundwater bores is insufficient to make a precise estimate of the $\mathrm{Cl}$ concentration of near-river groundwater. Elsewhere in southeast Australia, near-river groundwater is less saline than regional groundwater due to enhanced recharge on the floodplains (e.g. Cartwright et al., 2010). Thus, in common with other studies (e.g. Yu and Schwartz, 1999; Stewart et al., 2007; Gonzales et al., 2009), the highest $\mathrm{Cl}$ concentrations recorded in the Barwon River at Winchelsea during the low-flow periods when the river is most likely to be fed mainly or entirely by groundwater inflows will be used as the groundwater component. The highest $\mathrm{Cl}$ concentration recorded at Winchelsea between 2001 and 2011 when there is above zero discharge is $970 \mathrm{mg} \mathrm{L}^{-1}$, and this is used as the average $\mathrm{Cl}$ concentration of the groundwater. While this assumption introduces some uncertainties into the calculations, it is justified on the following grounds. Firstly, assigning a lower average groundwater $\mathrm{Cl}$ concentration results in the calculated baseflow fluxes (Eq. 3) being negative when the river has high $\mathrm{Cl}$ concentrations. Secondly, while assigning a higher $\mathrm{Cl}$ concentration to the groundwater component could be justified given the range of groundwater salinities in the catchment, this would imply that river at low discharge would always have a considerable component of surface water (which is unlikely during the prolonged very low discharge periods). Finally, in most years the highest $\mathrm{Cl}$ concentrations recorded in the river during the low flows in summer are similar (Fig. 7). This is most consistent with the inference that the river is groundwater fed at these times and that the river $\mathrm{Cl}$ concentration represents that of the groundwater rather than the groundwater having a higher $\mathrm{Cl}$ concentration and the river being fed by a similar mixture of groundwater and surface water. The $\mathrm{Cl}$ concentration of surface runoff was initially assumed to be $1.5 \mathrm{mg} \mathrm{L}^{-1}$, which is appropriate for local rainfall (Cartwright et al., 2013). As discussed below, surface runoff may have a higher salinity than rainfall, but this is the lowest possible value.

The baseflow fluxes calculated using chemical mass balance for 2001, 2002, and 2006 are $1.5 \times 10^{7} \mathrm{~m}^{3} \mathrm{yr}^{-1}(12 \%$ of total discharge), $9.9 \times 10^{6} \mathrm{~m}^{3} \mathrm{yr}^{-1}$ (25\% of total discharge) and $1.8 \times 10^{6} \mathrm{~m}^{3} \mathrm{yr}^{-1}$ (22\% of total discharge), respectively (Figs. 3-5, Table 1). Similar to the analytical methods, the baseflow fluxes estimated by this technique are again higher during the high-discharge periods later in the year. Between 2001 and 2011 the volume of baseflow estimated using chemical mass balance is $8.8 \times 10^{7} \mathrm{~m}^{3}$, which corresponds to $\sim 16 \%$ of the water discharged from the upper Barwon River over that period (Table 1).

\subsection{Comparison of chemical mass balance and the analytical techniques}

Overall, the baseflow fluxes calculated using the chemical mass balance are lower than those from the local minimum technique or either of the two digital filters; however, the degree of difference varies throughout the year. Figures $3 c, 4 c$ and $5 \mathrm{c}$ show the ratios of baseflow estimated from the local 


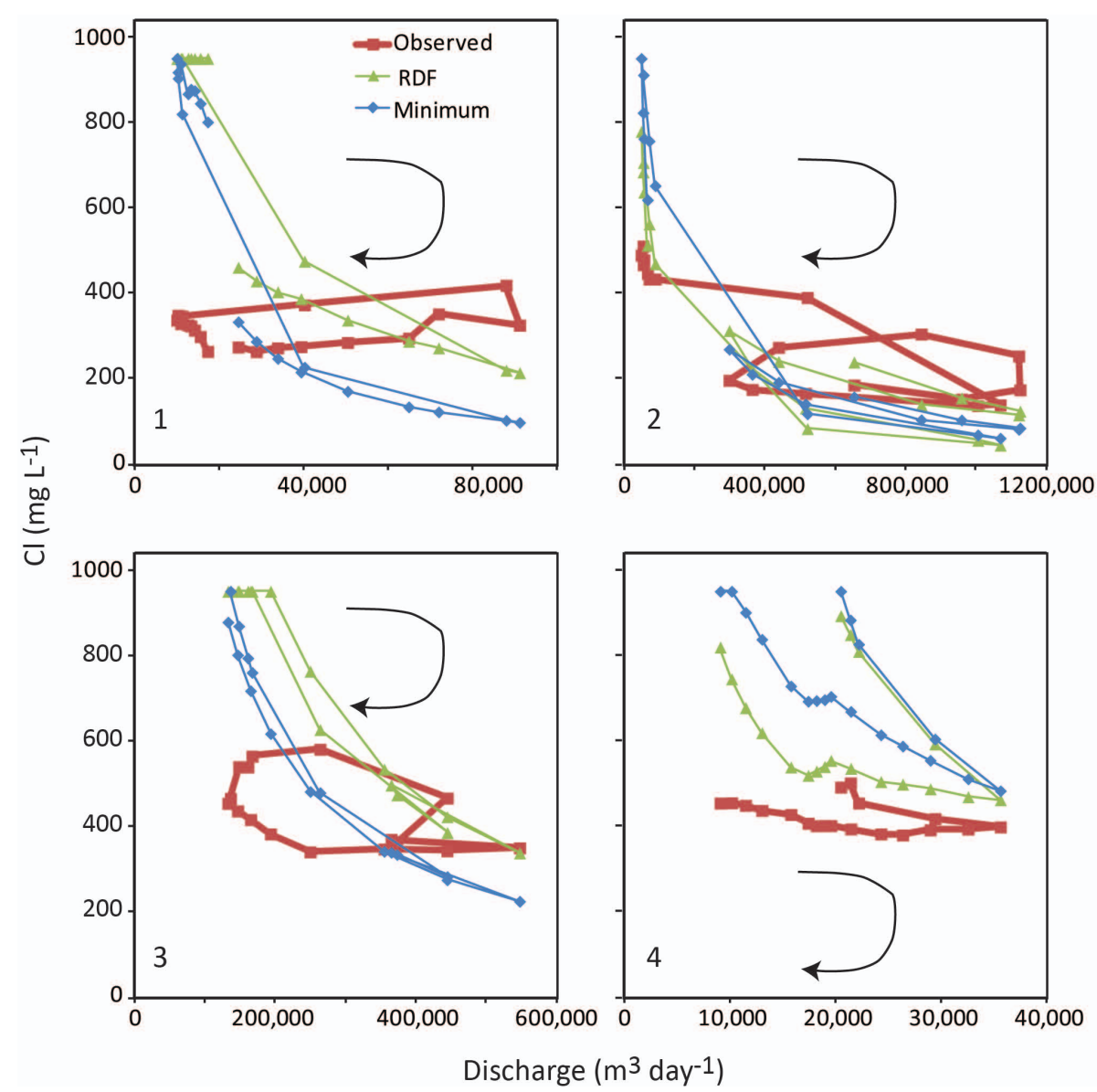

Fig. 8. Cl concentrations vs. discharge hysteresis loops for discharge events in 2002 at Winchelsea. Arrows show changes with time; numbers correspond to events on Fig. 4b. RDF and Min indicate the calculated $\mathrm{Cl}$ vs. discharge relationships made using the baseflow estimates from the Lyne and Hollock digital filter and the local minimum technique, respectively. These calculations assume that the analytical techniques yield estimates of the total baseflow to the river and that groundwater is the only component of baseflow. These calculations used a $\mathrm{Cl}$ concentration of $970 \mathrm{mg} \mathrm{L}^{-1}$ for groundwater and $23 \mathrm{mg} \mathrm{L}^{-1}$ for surface runoff.

minimum or the Lyne and Hollick filter and the chemical mass balance technique. These range from $<1$ at the onset of some of the discharge events (indicating that the chemical mass balance yields higher baseflow estimates at those times) to up to 8 during the high-flow periods in 2001 (indicating far lower baseflow estimates from the chemical mass balance technique). In general the baseflow fluxes estimated from the chemical mass balance are most similar to those from the analytical methods during the low-flow periods in late summer.

Especially at the onset of overland flow, surface runoff will most likely have a higher $\mathrm{Cl}$ concentration than that of rainfall due to flushing of saline water from soils or wetlands on the floodplain. This flushing probably explains the increase in salinity at the onset of some discharge events, as has been documented elsewhere (e.g. Aubert et al., 2012; Zabaleta and Antiguedad, 2013). The minimum $\mathrm{Cl}$ concentration in the river is $\sim 23 \mathrm{mg} \mathrm{L}^{-1}$, and concentrations similar to this are typically recorded during high-discharge events
(Fig. 7). Increasing the assumed $\mathrm{Cl}$ concentration of the surface water in the chemical mass balance reduces the estimated annual baseflow fluxes calculated using Eq. (3); for surface water with a $\mathrm{Cl}$ concentration of $23 \mathrm{mg} \mathrm{L}^{-1}$, the annual baseflow fluxes are $\sim 8 \%$ lower (i.e. $\sim 15 \%$ of total discharge). Increasing the groundwater salinity also decreases the estimated baseflow flux; for a groundwater $\mathrm{Cl}$ concentration of $1800 \mathrm{mg} \mathrm{L}^{-1}$, the total baseflow contribution is reduced to $\sim 8.5 \%$ of total discharge volumes between 2001 and 2011. As discussed above, groundwater and surface water $\mathrm{Cl}$ concentrations cannot be substantially lower than those assumed; hence, it is unlikely that uncertainties in assigning the chemistry of the end member can explain the difference between the two techniques. 

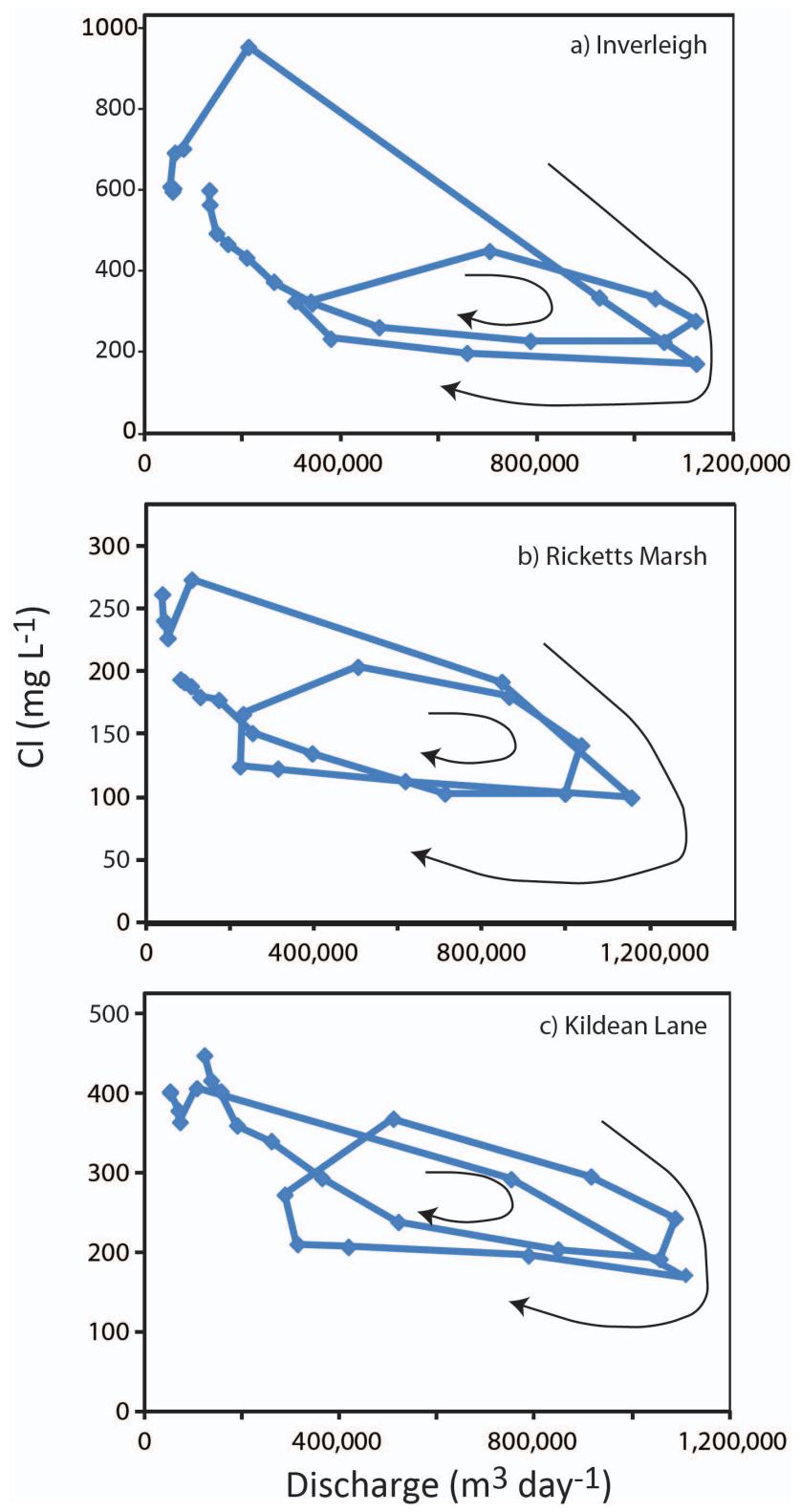

Fig. 9. $\mathrm{Cl}$ concentrations vs. discharge hysteresis loops for discharge events on days 170-200 in 2002 at Inverleigh, Ricketts Marsh, and Kildean Lane (Fig. 1); arrows show changes with time. This event corresponds to event 2 on Fig. 4.

\section{Discussion}

Estimates of annual baseflow fluxes in the upper Barwon River made using analytical methods are generally higher than those from chemical mass balance (Fig. 10). Baseflow fluxes from the digital filters, local minimum method, and the chemical mass balance generally agree during the low-flow periods in February to March when the river is most likely fed by regional groundwater. However, the differences between estimated baseflow fluxes are large during the period

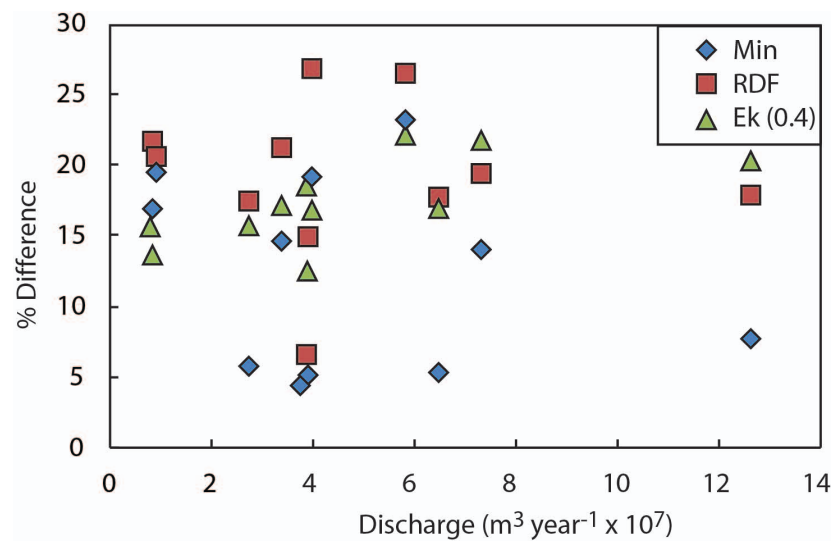

Fig. 10. Summary of the percentage difference of the estimated baseflow from the chemical mass balance technique and the local minimum (Min), the Lyne and Hollick digital filter (RDF) and the Eckhardt filter with $\mathrm{BFI}_{\max }=0.4(\operatorname{Ek}(0.4))$. Data from Table 1.

of higher winter flows (Figs. 4-6). The baseflow fluxes estimated from the chemical mass balance using the initial assumptions of groundwater and surface water $\mathrm{Cl}$ concentrations are maxima, and uncertainties in the groundwater and surface water chemistry cannot explain the differences in the results from the two sets of techniques.

Figure 8 illustrates that differences between the analytical and chemical techniques are evident within discharge events. Assuming that the analytical techniques yield estimates of the total baseflow to the river, the change in river $\mathrm{Cl}$ concentrations during a discharge event if groundwater was the only component of baseflow may be predicted from the proportion of baseflow and the chemistry of the groundwater and surface water components. These calculations used a $\mathrm{Cl}$ concentration of $970 \mathrm{mg} \mathrm{L}^{-1}$ for groundwater and $23 \mathrm{mg} \mathrm{L}^{-1}$ for surface runoff. The predicted $\mathrm{Cl}$ concentration on the rising limb of the hydrograph is lower than observed, while it is higher than observed on the falling limb; the predicted $\mathrm{Cl}$ vs. discharge loops are also steeper than the observed $\mathrm{Cl}$ vs. discharge loops. Changing the assumed surface runoff $\mathrm{Cl}$ concentrations (e.g. using the $1.5 \mathrm{mg} \mathrm{L}^{-1}$ rainfall composition) does not change these results significantly. Other gauges in the upper Barwon River show similar hysteresis loops (Fig. 9), implying that these Cl-discharge relationships are common throughout the catchment. Similar concentration vs. discharge hysteresis loops are evident in other catchments and indicate the rapid release of components from soils or the unsaturated zone during the early stages of the event followed by a gradual re-establishment of groundwater inflows following the diminishing of the event water (e.g. Evans and Davies, 1998; Hornberger et al., 2001; Aubert et al., 2012).

The difference between results of the analytical and chemical approaches most probably indicates a difference in how each method aggregates different sources of water rather than 
an error in any of the techniques. This in turn implies that water stores aside from surface runoff and regional groundwater inflow are important in the upper Barwon River and that the relative importance of these stores changes throughout the year.

\subsection{Transient water stores}

The floodplain of the upper Barwon contains numerous saline marshes and wetlands. Flushing of this saline water into the river during the onset of overland flow may produce relatively high $\mathrm{Cl}$ concentrations on the rising limbs of the hydrographs (Figs. 8 and 9), with the consequence that chemical mass balance overestimates the baseflow component at those times. Alternatively, high-salinity water may be expelled from the unsaturated zone or derived from enhanced groundwater inflows due to hydraulic loading on the floodplain. In the latter case, the $\mathrm{Cl}$ mass balance may still produce higher estimates of baseflow than the analytical techniques if the rates of groundwater inflows are greater than predicted from the analysis of the hydrographs. The input of older water entering rivers during storm events has been noted elsewhere (e.g. Sklash and Farvolden, 1979; Waddington et al., 1993; Rice and Hornberger, 1998; Brassard et al., 2000; Kirchner, 2009; Hrachowitz et al., 2011; Zabaleta and Antiguedad, 2013). In comparison to some of these studies (e.g. Rice and Hornberger, 1998; Kirchner, 2009; Hrachowitz et al., 2011) where older water is a major component throughout the flow events, the high-flow events in the Barwon have larger inputs of event water.

There may be several transient stores (e.g. bank storage, floodplain pools, or interflow) that provide low-salinity water on the falling limb of the hydrographs. Water recharged into the banks at high-river stage will return to the river as river levels fall, thus providing a component of baseflow over a period of weeks to months (e.g. Hall, 1968; Chen et al., 2006; McCallum et al., 2010). The study of McCallum et al. (2010) also illustrated that during a period of successive flood events the water infiltrating the river may contain significant bank return flows for periods of several months. This explains the observation that the $\mathrm{Cl}$ concentration of the upper Barwon River between the flood peaks is lower than Cl concentrations over prolonged low-flow periods when the banks have drained and the baseflow comprises mainly high-salinity regional groundwater (Figs. 3-5).

There are few processes that can increase the $\mathrm{Cl}$ concentration of bank water on timescales of a few weeks to months. As discussed above, the geochemistry of groundwater and surface water in the upper Barwon catchment precludes the dissolution of halite as a source of $\mathrm{Cl}$. Evapotranspiration is the main process that controls salinity in groundwater in this and adjacent catchments (Bennetts et al., 2006; Cartwright et al., 2009, 2013; Tweed et al., 2011). Evaporation rates may be rapid in surface water; however, evapotranspiration rates from depths of $2-3 \mathrm{~m}$ (which is the depth of the water table in the upper Barwon) in areas of shallow-rooted grasses and crops are likely to be slow. This assertion is supported by observations that groundwater at a few metres' depths in southeast Australia locally has total dissolved solids contents of $<100 \mathrm{mg} \mathrm{L}^{-1}$ but may have groundwater residence times of several ka (e.g. Leaney et al., 2003). If the water within river banks has a much lower $\mathrm{Cl}$ concentration than the regional groundwater, the analytical techniques are likely to record these bank return flows as part of the baseflow component, while the chemical mass balance may not account for this component.

It is likely that other transient water stores exist in the upper Barwon catchment. Pools and billabongs develop on the floodplain near the river during periods of high rainfall, especially when overbank events occur. These pools drain over periods of several days to weeks; some have surface water outflows, while others may drain into the river via the unsaturated zone or the shallow groundwater. Additionally, high rainfall may generate interflow that drains into the river over periods of days to months (c.f. Rice and Hornberger, 1998; Winter, 1999; Sophocleous, 2002; Brodie et al., 2007), which is a similar time frame to that over which the return of bank storage to rivers occurs. In the absence of processes that significantly increase their salinity on short timescales, these stores of water represent potential additional components of baseflow that are geochemically more similar to surface water than groundwater.

It is possible to explain some of the differences between chemical mass balance and the analytical techniques if the chemistry of groundwater that feeds the river varies at different times of the year. There are two possible mechanisms for this. Firstly, as evapotranspiration is the dominant process that controls the salinity of groundwater in this and adjacent catchments (Bennetts et al., 2006; Cartwright et al., 2013) there may be an increase in groundwater salinity over the summer months. While this remains a possibility, there is little evidence that groundwater salinity in this or similar catchments in southeast Australia is seasonally variable (e.g. from the unpublished Department of Primary Industries datasets). Additionally, most evapotranspiration occurs during recharge (c.f. Herczeg et al., 2001) and the baseflow to the river represents discharge of groundwater that is further along the flow paths. Rouxel et al. (2011) also observed that the temporal variation of groundwater chemistry in a forested upper catchment in France declined away from the recharge areas. Secondly, the groundwater may be derived from different regions at different times that have contrasting salinities. In the Barwon catchment there is no direct evidence that this occurs; however, many rivers in Victoria have lower-salinity groundwater along their floodplains that largely arises from enhanced recharge from the river during high-river stages (Cartwright et al., 2010, 2011), and this reservoir may be mobilised following recharge during wetter periods. This nearriver shallow groundwater is analogous to the bank return waters as it originates from the river rather than forming part 
of the regional groundwater flow system (albeit with longer timescales).

\subsection{Significance of the difference in baseflow estimates}

If the analytical methods are assumed to reflect total baseflow to the river and the chemical mass balance the groundwater inflow, the magnitude of the difference between the methods may indicate the relative contribution of the transient water stores. For 2002, the total estimate is $7.6 \times 10^{6}$ to $1.0 \times 10^{7} \mathrm{~m}^{3} \mathrm{yr}^{-1}$, or 19 to $27 \%$ of the total river discharge. As these calculations do not take into account the potential flushing of high-salinity water from the floodplain during the early stages of discharge events, they are minimum estimates. As shown by Fig. 10, there is no clear relationship between annual river discharge and the difference between the analytical and chemical baseflow estimates. This indicates that generation of the transient stores of water may depend more on the timing and frequency of high-runoff events rather than total annual discharge.

\section{Conclusions}

This study illustrates that geochemical and analytical methods of estimating baseflow yield contrasting results. While all the techniques used are subject to uncertainty, the systematic nature of the differences (especially the observation that the difference between the analytical techniques and chemical mass balance is greatest during winter high-flow periods) implies that the uncertainties in the techniques alone do not explain the contrasting results. We conclude that the contrasting results reflect how the different methods characterise the water sources to rivers. The analytical methods probably aggregate all delayed water sources as baseflow components. Many of these delayed water sources (such as bank flow, interflow, or floodplain storage) will have a geochemistry that is similar to that of surface runoff, and geochemical mass balance techniques aggregate them with the surface runoff. These transient stores of water impact the catchment for several weeks to months following rainfall events and during periods of high rainfall may dominate the non-surface water component of river flow. These results indicate that where techniques separate river flow into two components there is no a priori reason why there should be agreement between techniques based on different types of data but that the differences may contain important hydrological information. The stores of water contributing to the Barwon River change over weeks to months, which is similar to the timescale over which water stores in other catchments change (e.g. McCallum et al., 2010; Aubert et al., 2012; Hrachowitz et al., 2011, 2013). In general, there will be a scaling of response time to catchment areas with medium-sized catchments such as the upper Barwon showing transitions between water stores on longer timescales than smaller catchments.

This study amplifies the conclusions made elsewhere that assigning the origins of the quickflow and baseflow components is not simple (e.g. Hall, 1968; Anderson and Burt, 1980; Brodie et al., 2007; Schwartz, 2007; McCallum et al., 2010) and also illustrates that the components of water contributing to baseflow may change throughout the year. Records of surface water geochemistry are gradually becoming more common, making it viable to use comparisons between chemical mass balance and analytical techniques to better understand the changing sources of water that contribute to rivers over discharge events. Ideally multiple tracers would be applied that may distinguish between groundwater and other subsurface stores of water such as interflow or bank return flow (e.g. Rice and Hornberger, 1998); however, since there are few chemical components that may be measured continuously, this presents logistical difficulties. Changing groundwater chemistry has received little attention in chemical mass balance studies; however, it should be evaluated more fully to increase the robustness of baseflow estimates.

The results of this study have implications for managing groundwater and surface water resources. There is a recognition that neglecting the groundwater inflows to rivers may lead to double allocation of water resources (i.e. some of the surface water allocation may represent groundwater that has been separately allocated). However, the use of analytical methods alone may result in overestimation of regional groundwater inputs to rivers if a significant part of the baseflow component is from transient water stores such as bank return flow or draining of surface pools on the floodplain.

Acknowledgements. We would like to thank the Department of Sustainability and Environment for their ongoing support of the Victorian Water Resources Data Warehouse without which studies such as this would not be possible. This work was supported by the P3 program of the ARC-NWI-funded National Centre for Groundwater Research and Training. The comments by T. McMahon, M. Hrachowitz and four anonymous reviewers improved this work considerably and are gratefully acknowledged.

Edited by: R. Woods

\section{References}

Ahearn, D. S., Sheibley, R. W., Dahlgren, R. A., and Keller, K. E.: Temporal dynamics of stream water chemistry in the last freeflowing river draining the western Sierra Nevada, California, J. Hydrol., 295, 47-63, 2004.

Aksoy, H., Kurt, I., and Eris, E.: Filtered smoothed minima baseflow separation method, J. Hydrol., 372, 94-101, 2009.

Anderson, M. G. and Burt, T. P.: Interpretation of Recession Flow, J. Hydrol., 46, 89-101, 1980. 
Aubert, A. H., Gascuel-Odoux, C., and Merot, P.: Annual hysteresis of water quality: a method to analyse the effect of intra- and interannual climatic conditions, J. Hydrol., 478, 29-39, 2012.

Bennetts, D. A., Webb, J. A., Stone, D. J. M., and Hill, D. M.: Understanding the salinisation process for groundwater in an area of south-eastern Australia, using hydrochemical and isotopic evidence, J. Hydrol., 323, 178-192, 2006.

Brassard, P., Waddington, J. M., Hill, A. R., and Roulet, N. T.: Modelling groundwater-surface water mixing in a headwater wetland: Implications for hydrograph separation, Hydrol. Process., 14, 2697-2710, 2000.

Brodie, R., Sundaram, B., Tottenham, R., Hostetler, S., and Ransley, T.: An overview of tools for assessing groundwater-surface water connectivity, Bureau of Rural Sciences, Canberra, p. 133, 2007.

Bureau of Meteorology: Commonwealth of Australia Bureau of Meteorology, http://www.bom.gov.au, last access: 1 December 2012 .

Cartwright, I., Hall, S., Tweed, S., and Leblanc, M.: Geochemical and isotopic constraints on the interaction between saline lakes and groundwater in southeast Australia, Hydrogeol. J., 17, 19912004, 2009.

Cartwright, I., Weaver, T. R., Simmons, C. T., Fifield, L. K., Lawrence, C. R., Chisari, R., and Varley, S.: Physical hydrogeology and environmental isotopes to constrain the age, origins, and stability of a low-salinity groundwater lens formed by periodic river recharge: Murray Basin, Australia, J. Hydrol., 380, 203-211, 2010.

Cartwright, I., Hofmann, H., Sirianos, M. A., Weaver, T. R., and Simmons, C. T.: Geochemical and ${ }^{222} \mathrm{Rn}$ constraints on baseflow to the Murray River, Australia, and timescales for the decay of low-salinity groundwater lenses, J. Hydrol., 405, 333-343, 2011.

Cartwright, I., Gilfedder, B., and Hofmann, H.: Chloride imbalance in a catchment undergoing hydrological change: Upper Barwon River, southeast Australia, Appl. Geochem., 31, 187-198, 2013.

Chen, X., Chen, D. Y., and Chen, X. H.: Simulation of baseflow accounting for the effect of bank storage and its implication in baseflow separation, J. Hydrol., 327, 539-549, 2006.

Cook, P. G.: Estimating groundwater discharge to rivers from river chemistry surveys, Hydrol. Process., 27, 3694-3707, doi:10.1002/hyp.9493, 2013.

Corangamite Catchment Management Authority: The Environmental Flow Determination for the Barwon River, Geelong, Australia, p. 138,2005

Dahlhaus, P., Cox, J., Simmons, C., and Smitt, C.: Beyond hydrogeologic evidence: challenging the current assumptions about salinity processes in the Corangamite region, Australia, Hydrogeol. J., 16, 1283-1298, 2008.

Davis, S. N., Whittemore, D. O., and Fabryka-Martin, J.: Uses of chloride/bromide ratios in studies of potable water, Ground Water, 36, 338-351, 1998.

Dye, P. J. and Croke, B. F. W.: Evaluation of streamflow predictions by the IHACRES rainfall-runoff model in two South African catchments, Eviron. Model. Softw., 18, 706-712, 2003.

Eckhardt, K.: How to construct recursive digital filters for baseflow separation, Hydrol. Process., 19, 507-515, 2005.

Eckhardt, K.: A comparison of baseflow indices, which were calculated with seven different baseflow separation methods, J. Hydrol., 352, 168-173, 2008.
Evans, C. and Davies, T. D.: Causes of concentration/discharge hysteresis and its potential as a tool for analysis of episode hydrochemistry, Water Resour. Res., 34, 129-137, 1998.

Gonfiantini, R.: Environmental isotopes in lake studies, in: Handbook of Environmental Isotope Geochemistry, Vol. 2 the Terrestrial Environment, edited by: Fritz, P. and Fontes, J. C., Elseveir, Amsterdam, 113-186, 1986.

Gonzales, A. L., Nonner, J., Heijkers, J., and Uhlenbrook, S.: Comparison of different base flow separation methods in a lowland catchment, Hydrol. Earth Syst. Sci., 13, 2055-2068, doi:10.5194/hess-13-2055-2009, 2009.

Hall, F. R.: Baseflow Recessions - A Review, Water Resour. Res., 4, 973-983, 1968.

Herczeg, A. L., Dogramaci, S. S., and Leaney, F. W.: Origin of dissolved salts in a large, semi-arid groundwater system: Murray Basin, Australia, Mar. Freshwater Res., 52, 41-52, 2001.

Hornberger, G. M., Scanlon, T. M., and Raffensperger, J. P.: Modelling transport of dissolved silica in a forested headwater catchment: The effect of hydrological and chemical time scales on hysteresis in the concentration-discharge relationship, Hydrol. Process., 15, 2029-2038, 2001.

Hrachowitz, M., Bohte, R., Mul, M. L., Bogaard, T. A., Savenije, H. H. G., and Uhlenbrook, S.: On the value of combined event runoff and tracer analysis to improve understanding of catchment functioning in a data-scarce semi-arid area, Hydrol. Earth Syst. Sci., 15, 2007-2024, doi:10.5194/hess-15-2007-2011, 2011.

Hrachowitz, M., Savenije, H., Bogaard, T. A., Tetzlaff, D., and Soulsby, C.: What can flux tracking teach us about water age distribution patterns and their temporal dynamics?, Hydrol. Earth Syst. Sci., 17, 533-564, doi:10.5194/hess-17-533-2013, 2013.

Kirchner, J. W.: Catchments as simple dynamical systems: Catchment characterization, rainfall-runoff modeling, and doing hydrology backward, Water Resour. Res., 45, W02429, doi:10.1029/2008WR006912, 2009.

Leaney, F. W., Herczeg, A. L., and Walker, G. R.: Salinization of a fresh palaeo-ground water resource by enhanced recharge, Ground Water, 41, 84-92, 2003.

Lyne, V. and Hollick, M.: Stochastic time variable rainfall runoff modeling, Proceedings, National Committee on Hydrology and Water Resources of the Institution of Engineers, Australia 79/10, Institute of Engineers, Canberra, Australia, 89-93, 1979.

McCallum, J. L., Cook, P. G., Brunner, P., and Berhane, D.: Solute dynamics during bank storage flows and implications for chemical base flow separation, Water Resour. Res., 46, W07541, doi:10.1029/2009WR008539, 2010.

Mullinger, N. J., Binley, A. M., Pates, J. M., and Crook, N. P.: Radon in Chalk streams: Spatial and temporal variation of groundwater sources in the Pang and Lambourn catchments, UK, J. Hydrol., 339, 172-182, 2007.

Nathan, R. J. and McMahon, T. A.: Evaluation of automated techniques for base flow and recession analyses, Water Resour. Res., 26, 1465-1473, 1990.

Petrides, B. and Cartwright, I.: The hydrogeology and hydrogeochemistry of the Barwon Downs Graben aquifer, southwestern Victoria, Australia, Hydrogeol. J., 14, 809-826, 2006.

Rice, K. and Hornberger, G. M.: Comparison of hydrochemical tracers to estimate source contributions to peak flow in a small, forested, headwater catchment, Water Resour. Res., 34, 17551766, 1998. 
Rouxel, M., Molenat, J., Ruiz, L., Legout, C., Faucheux, M., and Gascuel-Odoux, C.: Seasonal and spatial variation in groundwater quality along the hillslope of an agricultural research catchment (Western France), Hydrol. Process., 25, 831-841, 2011.

Sanford, W. E., Nelms, D. L., Pope, J. P., and Selnick, D. L.: Quantifying components of the hydrologic cycle in Virginia using chemical hydrograph separation and multiple regression analysis, USGS Scientific Investigations Report 2011-5198, Reston, VA, USA, p. 152, 2012.

Schwartz, S. S.: Automated algorithms for heuristic base-flow separation, J. Am. Water Resour. As., 43, 1583-1594, 2007

Sklash, M. G. and Farvolden, R. N.: The role of groundwater in storm runoff, J. Hydrol., 43, 45-65, 1979

Sloto, R. A. and Crouse, M. Y.: HYSEP: A Computer Program for Streamflow Hydrograph Separation and Analysis, US Geol. Surv. Water-Resources Investigations Report 964040 46, Lemoyne, Pennsylvania, USA, 1996.

Sophocleous, M.: Interactions between groundwater and surface water: the state of the science, Hydrogeol. J., 10, 52-67, 2002.

Stewart, M., Cimino, J., and Mark, R.: Calibration of base flow separation methods with streamflow conductivity, Ground Water, 45, 17-27, 2007.

Tweed, S., Grace, M., Leblanc, M., Cartwright, I., and Smithyman, D.: The individual response of saline lakes to a severe drought, Sci. Total Environ., 409, 3919-3933, 2011.

Uhlenbrook, S., Frey, M., Leibundgut, C., and Maloszewski, P.: Hydrograph separations in a mesoscale mountainous basin at event and seasonal timescales, Water Resour. Res., 38, 31-1-31-14, doi:10.1029/2001WR000938, 2002.
Waddington, J. M., Roulet, N. T., and Hill, A. R.: Runoff mechanisms in a forested groundwater discharge wetland, J. Hydrol., 147, 37-60, 1993.

Water Resources Data Warehouse: Victoria Department of Sustainability and Environment Water Resources Data Warehouse, www.vicwaterdata.net/vicwaterdata/home.aspx, last access: 5 December 2012.

Winter, T. C.: Relation of streams, lakes, and wetlands to groundwater flow systems, Hydrogeol. J., 7, 28-45, 1999.

Winter, T. C.: The vulnerability of wetlands to climate change: A hydrologic landscape perspective, J. Am. Water Resour. As., 36, 305-311, 2000.

Witebsky, S., Jayatilaka, C., and Shugg, A.: Groundwater development options and environmental impacts Barwon Downs Graben, southwestern Victoria, Victoria Department of Natural Resources and Environment Report, Melbourne, Australia, 1995.

Wittenberg, H. and Sivapalan, M.: Watershed groundwater balance estimation using streamflow recession analysis and baseflow separation, J. Hydrol., 219, 20-33, 1999.

Yu, Z. and Schwartz, F. W.: Automated calibration applied to watershed-scale flow simulations, Hydrol. Process., 13, 191209, 1999.

Zabaleta, A. and Antigüedad, I.: Streamflow response of a small forested catchment on different timescales, Hydrol. Earth Syst. Sci., 17, 211-223, doi:10.5194/hess-17-211-2013, 2013. 